\title{
The effect of diversification on firm performance: Evidence from Listed Companies in Vietnam
}

\author{
${ }^{1}$ Thi Thu Bui, ${ }^{2}$ Quynh Mai Ha, ${ }^{3}$ Dai Long Khuc \\ ${ }^{1}$ Lecturer, Faculty of Economics, Natural Resources and Environment, Hanoi University of Natural \\ Resources and Environment, Vietnam. \\ ${ }^{2}$ Lecturer, Faculty of Economics, Natural Resources and Environment, Hanoi University of Natural \\ Resources and Environment, Vietnam. \\ ${ }^{3}$ Lecturer, Faculty of Marketing, Thuongmai University, Vietnam.
}

\begin{abstract}
The study was conducted to investigate the relationship between diversification on Board and firm performance. The investigation has been performed using panel data procedure for a sample of 204 Vietnamese listed companies in two different groups: Large cap and Mid cap, listed in HOSE and HNX during the period of five years from 2015 to 2019. The study uses three performance measures (including return on equity, return on asset, Tobin's Q) as dependent variable. The independent variables for measurement of diversification on Board are the number of females and the diversification for Supervisory Board are the number of females only. Other independent variables are average age of Board member, CEO duality and the number of independent directors. The results indicated that firm performance have positive relationship with nationality diversity on Board and gender diversity on Supervisory Board. CEO duality shows a significant result of negative effect on firm performance.
\end{abstract}

Key words: firm performance, diversification, Tobin's Q, Vietnam

\section{Introduction}

Nowadays, woman play more and more important role in business. The increasing in diversity should be an essential social trend (Adams, Daniel, 2009) because they can offer different management approach compared to men. The most well-known argument is that women and men can have similarly level of education and working abilities to occupy the same position in a corporation. Moreover, gender psychology emphasizes that there are many differences in cognitive functioning between two gender. Reguera Alvarado et al. (2015) considered that women tend to be more risk adverse and more sensitive than men, they might not take many risky opportunities of investment even these returns can be significant. As a result, the company may not suffer from too many risky portfolios, but the growth rate of corporation seems to be more stable rather than high growth in the future.

Moreover, the concept of corporate governance should be considered as an important factor in a corporation. It is the concept of structure and procedures system of the management team to balance the interest among different stakeholders. Corporate governance plays an important role in effective business decision making in order to improve firm performance, extend business and solving problems in financial difficulties. Kemp (2006) stated that good corporate governance practices leads to an effective board management behavior, therefore, it will improve the business performance. In the study, the structure of Board of Director will be investigated by the influence of independent director and CEO duality on firm performance during a period of time.

Regarding the scope of this study, the researcher wants to focus on Vietnamese market due to several reasons:

Firstly, Vietnam is a developing country with high growth rate as well as many potential developments in the future. Because this study will use the data from listed companies in HOSE and HNX Stock Exchange, 
the firm performance and corporate governance of companies can be considered as the most important observation for investors when finding investment opportunities. Moreover, the corporate governance in Vietnam becomes one of the most debated topics recently due to practical problem raising recently. However, the number of quantitative research related to this topic is shortage as well as several limited in scope and quality still exist in recent studies.

\section{Literature review}

\subsection{Board Independence}

In a corporation, the board of director plays an important role in the development as well as the operating activities of corporation. The definition of board of directors is stated as "elected or appointed members who jointly oversee the activities of a corporation or organization". The board of director is represented for shareholders of a corporation and they are supposed to act for shareholders' interests. Carter et al. (2010) emphasized the role of Board of Directors in the corporation through four key parts that involves in "monitoring and controlling managers, providing information and counsel to managers, monitoring compliance with applicable laws and regulations, and linking the corporation to the external environment". The most well-known theory applied for determining the attribution of board of directors is the agency theory. This theory emphasizes on the terminology of "independent director" as a determinant of firm performance. Independent director work for the company as outside party for reviewing the firm performance, therefore, they can give more true and fair view of business activities.

In 1990, two researchers defined that there is a positive relation between an increase in the proportion of the independent director and market value of firm. By using 1251 announcements from outside directors as sample, this study also determined the positive correlation between the number of independent directors and firm value (Rosenstein, Wyatt, 1990). The positive influence of board independent on firm performance was investigated through three different variables: proportion of independent director, committee overlap and board interlock (Robert W. Rutledge, Khondkar E. Karim, Siyu Lu, 2016).

There will be a potential benefit of independent director for the corporation because of improvement in corporate governance (Ritchie, 2007). This benefit is expressed by their dominant experience and knowledge regarding the industry. The study also recommend that international firm should appoint independent directors in order to improve the firm performance and develop successful internationalization process (Chen et al. 2016).

\subsection{CEO Duality}

CEO duality refers to the two important positions in a corporation CEO and Chairman are presented by only one person. CEO duality or separation was becoming a debated topic in several years. One argument is that the potential cost of separation will dominant the potential benefit (Brickley, Coles \& Jarrell, 1997). Several studies indicated significant relationship between CEO duality and firm performance (Cochran, Wood, and Jones, 1985) due to enhancing the conformity in the workplace (Tricker, 1994), making decisions and responses more quickly under uncertainty circumstance (Boyd, 1995). This study supported for Stewardships theory, which indicated that the manager would make better decision regarding to both CEO's interest and shareholders' interest (Boyd et al. 1997).

On the negative side, the separating between CEO and Chairman of corporation to make it more effectively by eliminating many conflicts as well as crises in corporation (Lorsch, 1989). CEO separation also makes the corporation more transparency and reduce conflict of interest, therefore, board leadership would improve appreciably over time if the board chairman were not part of the active management (Patton and Baker, 1987). The negative relationship between CEO duality and firm performance are investigated in European listed firm from the Fortune Global 500 (Huining Chen, 2014), in the banking industry (Pi and Timme, 1993) or in listed companies in Vietnam.

\subsection{Board Diversity}

Diversity in board members has become one of the most debated topics in recent decade, a lot of investigations were created to determine the impact of boards' diversity on business activities as well as firm performance.

\section{Gender diversity:}


One of the most significant factor of diversity topic is gender. Compared to men, women usually occupied fewer board seats. The gender diversity is classified as the percentage of women standing on board of member in a corporation. The great percentage of women at the managerial level would develop the firm performance by increasing several financial ratios such as ROS, ROI, ROA and ROE (Shrader et al. 1997) and Tobin's Q ratio (David, 2003). Other measurement method applied was the board effectiveness measurement. One of reason is conducted by observation of annual meeting of shareholders, women have shown more frequency records of attendant than men did. The researcher think that it will reduce the monitoring problem in the corporation (Renée, Daniel, 2017).

The benefits of diversity related to gender characteristics, namely diverse of experience, knowledge, and behavior in decision - making process (Alireza, Kamram, Paul, 2015). Several studies explain the reason of positive result such as increasing variety of opinions and problem solving in boardroom, improving the leadership styles, and creating innovation, developing the working environment and reputation of companies (Carter et al. 2003). Another motive of diversification is to reduce the conflicts among the directors' member and create more effective management (Nielsen, Huse, 2010).

Recently, a study investigates the cross-cultural impact of CEO duality gender to the firms' bribery. The result shows that male manager involved in bribery activities more often than women ones due to differences in decision making process, male often concern more about economic goal rather than female and therefore, male are willing to do unethical decisions more frequently than women (Kristine, Chung-wen, 2017).

\section{Foreign directors - Nationality:}

Many studies recently show that foreign director is an important factor of diversification. A definition of board nationality diversity is given as "the minority representation on the board". The Hofsetde - Gray cultural model is an efficient method of analyzing different characteristics among people coming from other countries. The diversity in culture would bring a lot of potential benefit for corporation (Nermeen, 2013). Normally, almost foreign directors do not have close relationship with other member in a board, as a result, they can benefit for the corporation by providing opinions because of their differences in values, norms and believes. Therefore, it will create a lot of benefits for management activities and innovation creation (Ruigrok et al. 2007).

The positive influence can be seen with a significant amount in developing countries and emerging market rather than developed countries due to less strict regulation, lower legal and function quality (Miletkov et al. 2017). Moreover, nationality diversity is positively and significantly associated with shareholder heterogeneity and the firm's international market business and firm operating performance (Estélyi, Nisar, 2016).

Opponent view was determined by the negative impacts on firm performance. Using Tobin's Q and ROA as dependent variables, the study also determined that the level of negative impact is not the same for all companies due to differences in size, complexity of operating business activities and the proportion of foreigners appointed in independent directors (Bart, Olga, Helena, 2016). Foreign directors often lack duties and attention on financial statement, weaken the process of controlling and monitoring CEO's activities, reduce the corporate governance of companies (Ronald, 2007).

\section{Knowledge and experience:}

The number of studies investigating the effect of knowledge and experience diversity of board member individually is a small number. The important of diversity in knowledge and skill also can be founded by Simons and Pelled (1999). They believe that board member should have different knowledge in variety sectors such as finance, legal, human resources to make better decision for the companies. Moreover, international working experience of board member can be seen as one of important factor leading to better firm performance, especially in short-term (Maznevski, 1994; Murray, 1989).

Several concepts related to this field were developed such as "directors' industry experience" (number of working - years in the industry) and "education diversity" (level of education and types of degree). These concepts have positive influence on firm performance due to the difference of directors' beliefs, perspectives, and preferences. The researcher believes that directors with different background, experience and education will react in different ways and take different solutions at the same situation (Mariassunta, Mengxin, 2015). 


\section{Data and methodology}

\subsection{Data}

The research used the sample of 204 listed companies in two different groups (Large cap and Mid cap), which divided based on the market capitalization. The secondary data was employed by the financial statement of 204 listed companies on Ho Chi Minh Stock Exchange (HOSE) and Hanoi Stock Exchange (HXS) during the period from 2015 to 2019.

The study did not contain all Mid cap companies listed in both stock exchange due to lack of information. In the period of 5 years, a lot of companies are delisted or newly listed in the stock exchange. Therefore, it will be difficult for collecting all information of these companies, especially the corporate governance information.

\subsection{Research Model}

Regarding the purpose of the study is quantifying the impact of board diversification on the firm performance, the regression model for panel data has been used. The primary reason for using panel data is that this model provides more information, little multicollinearity between the variables, more efficient as well as offers opportunity for controlling unobserved individual or time specific heterogeneity, which may be correlated with the included explanatory variables.

This study used Pooled OLS, FEM and REM for estimation of the data. A balanced panel data set is used, which has equal number of observations for each (cross-section) and best model selection. REM versus FEM is chosen by using Hausman specification test and Breusch-Pagan Lagrange Multiplier test. The general form of Panel Data Model:

$\mathrm{Yt}=\mathrm{m}+\beta 0+\beta 1 \times \mathrm{X} 1$ it $\mathrm{X} 2$ it $+\ldots+\beta \mathrm{n} * \mathrm{Xnit}+\mathrm{ut}$

Where:

$\mathrm{i}$ is the ith cross section, and $\mathrm{t}$ is the time $\mathrm{t}$

Y: The dependent variable

$\mathrm{X}$ : Independent variables

In general, the research model presented below will be used for empirical purposes:

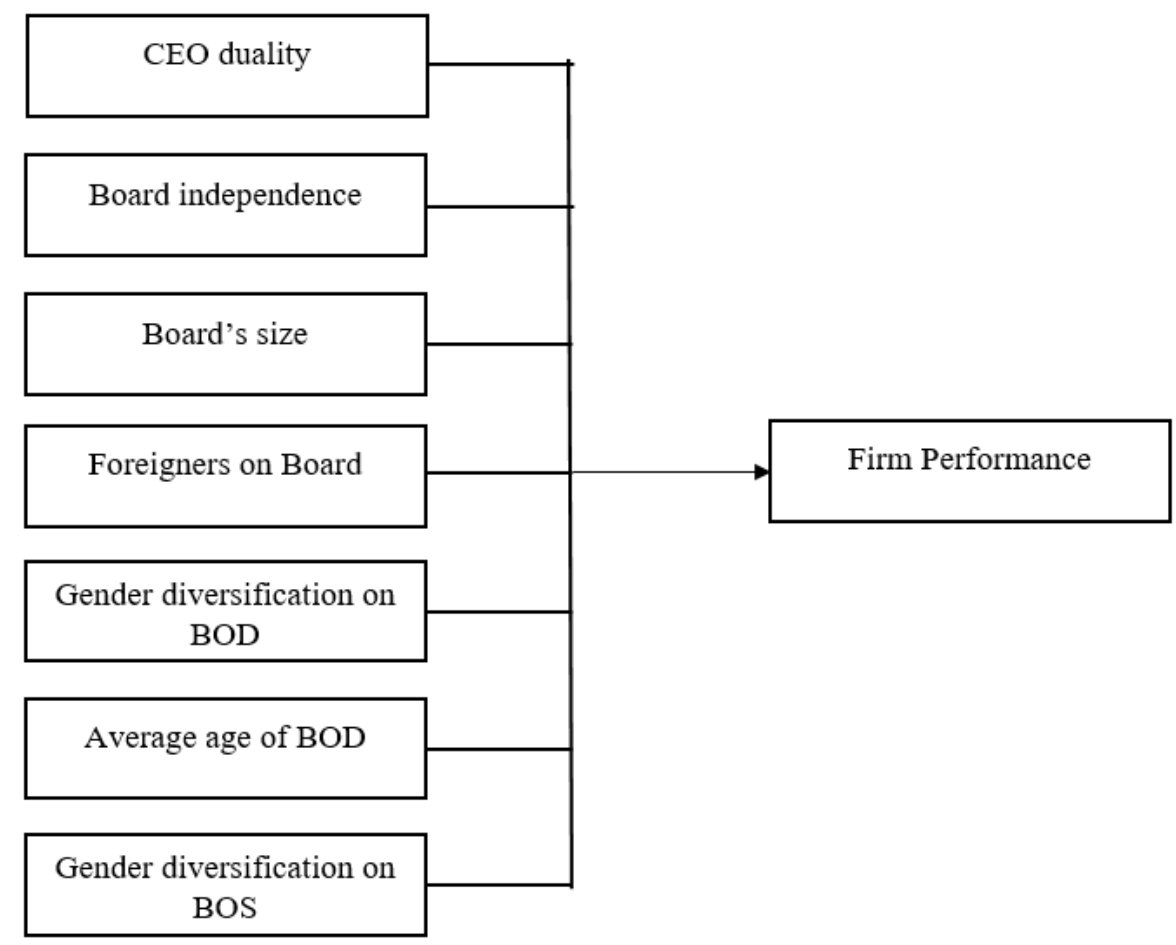

Figure 1. Research Model

\subsection{Variables}

The variables of this study are described in the following table

\begin{tabular}{|l|l|l|}
\hline VARIABLES & MEASUREMENT & CLASSIFICATION \\
\hline
\end{tabular}




\begin{tabular}{|c|c|c|}
\hline \multicolumn{3}{|c|}{ DEPENDENT VARIABLES } \\
\hline ROA & Return on Asset $=$ Net Income $/$ Total Asset $\times 100 \%$ & Continuous variable \\
\hline ROE & Return on Equity $=$ Net Income $/$ Total Equity $\times 100 \%$ & Continuous variables \\
\hline TOBIN'S Q & Tobin's Q = Market capitalization/ Total Asset & Continuous variables \\
\hline \multicolumn{3}{|c|}{ INDEPENDENT VARIABLES } \\
\hline BOD & Number of people in BOD & Discrete variables \\
\hline FEBOD & Number of females in BOD & Discrete variables \\
\hline FORE & Number of foreigners in BOD & Discrete variables \\
\hline BOS & Number of people in BOS & Discrete variables \\
\hline ID & $\begin{array}{l}\text { Independent director in BOD } \\
\text { (Code " } 1 \text { " if the company has at least } 1 \text { independent director and " } 1 \text { " for } \\
\text { other cases) }\end{array}$ & Dummy variables \\
\hline $\mathrm{CEO}$ & $\begin{array}{l}\text { CEO duality in corporation } \\
\text { (Code " } 1 \text { " if CEO and Chairman are the same person and " } 0 \text { " for other } \\
\text { cases) }\end{array}$ & Dummy variables \\
\hline AGE & $\begin{array}{l}\text { Average age of BOD } \\
\text { (Code " } 1 \text { " if average age of BOD higher than } 45 \text { years old and " } 0 \text { " for } \\
\text { other cases) }\end{array}$ & Dummy variable \\
\hline \multicolumn{3}{|c|}{ CONTROL VARIABLES } \\
\hline INDUS1 & $\begin{array}{l}\text { Finance, Insurance and Real Estate } \\
\text { (Code "1" if the company belongs to the industry and " } 0 \text { " for other } \\
\text { cases) }\end{array}$ & \multirow{6}{*}{ Dummy variable } \\
\hline INDUS2 & $\begin{array}{l}\text { Transportation, Communications, Electric, Gas and Sanitary service } \\
\text { (Code "1" if the company belongs to the industry and " } 0 \text { " for other } \\
\text { cases) }\end{array}$ & \\
\hline INDUS3 & $\begin{array}{l}\text { Construction } \\
\text { (Code " } 1 \text { " if the company belongs to the industry and " } 0 \text { " for other } \\
\text { cases) }\end{array}$ & \\
\hline INDUS4 & $\begin{array}{l}\text { Trade } \\
\text { (Code " } 1 \text { " if the company belongs to the industry and " } 0 \text { " for other } \\
\text { cases) }\end{array}$ & \\
\hline INDUS5 & $\begin{array}{l}\text { Manufacturing } \\
\text { (Code " } 1 \text { " if the company belongs to the industry and " } 0 \text { " for other } \\
\text { cases) }\end{array}$ & \\
\hline INDUS6 & $\begin{array}{l}\text { Services } \\
\text { (Code " } 1 \text { " if the company belongs to the industry and " } 0 \text { " for other } \\
\text { cases) }\end{array}$ & \\
\hline
\end{tabular}

\section{Data analysis and results}

\subsection{Statistical Results}

Table 1. Descriptive statistics of variables

\begin{tabular}{|l|r|r|r|r|r|}
\hline \multicolumn{1}{|c|}{ Variables } & \multicolumn{1}{c|}{ Obs } & \multicolumn{1}{c|}{ Mean } & \multicolumn{1}{c|}{ Min Dev. } & \multicolumn{1}{c|}{ Max } \\
\hline ROA $(\%)$ & 1,020 & 7.58090 & 8.31844 & -36.42 & 83.90 \\
\hline ROE $(\%)$ & 1,020 & 15.74973 & 17.06411 & -168.72 & 293.09 \\
\hline QTOBINS & 1,020 & 0.8821188 & 0.9797067 & 0.04 & 7.8 \\
\hline BOD & 1,020 & 6.301916 & 1.56225 & 1 & 13 \\
\hline ID & 1,020 & 0.9598039 & 0.8734172 & 0 & 4 \\
\hline CEO & 1,020 & 0.2441176 & 0.4297736 & 0 & 1 \\
\hline AGE & 1,020 & 0.7215686 & 0.4484468 & 0 & 1 \\
\hline FORE & 1,020 & 0.5147826 & 0.8651442 & 0 & 5 \\
\hline FEBOD & 1,020 & 1.226471 & 1.092703 & 0 & 6 \\
\hline
\end{tabular}




\begin{tabular}{|l|r|r|r|r|r|}
\hline BOS & 1,020 & 3.191176 & 0.5773961 & 2 & 6 \\
\hline FEBOS & 1,020 & 1.636275 & 1.098691 & 0 & 4 \\
\hline
\end{tabular}

Source: Calculated from the Stata Analysis Regarding the dependent variables, ROA could vary from $-36.42 \%$ to $83.90 \%$ and its mean stays at $7.58 \%$. These numbers could change by approximately $8.3 \%$ around the mean of ROA. Return on equity, ROE also lays from the minimum rate of $-168.72 \%$ to the maximum rate of $239.09 \%$. The average value of ROE could be $15.75 \%$, which standard deviation is around $17.06 \%$. Finally, the Tobin's Q figure reaches the highest figure of 7.8 and the lowest one of 0.04 while the mean and sd are around 0.88 and 0.98 , respectively.

Another aspect should be mentioned is the correlation among all variables in this study, which will be described as the table below

\section{Table 2. Correlation of variables}

\begin{tabular}{|c|c|c|c|c|c|c|c|c|c|c|c|}
\hline & ROA & ROE & QTOBINS & BOD & ID & CEO & FORE & AGE & FEBOD & BOS & FEBOS \\
\hline ROA & 1.0000 & & & & & & & & & & \\
\hline ROE & 0.5892 & 1.0000 & & & & & & & & & \\
\hline QTOBINS & 0.4829 & 0.2315 & 1.0000 & & & & & & & & \\
\hline BOD & -0.0632 & -0.0287 & -0.0527 & 1.0000 & & & & & & & \\
\hline ID & 0.0758 & 0.0872 & 0.1034 & 0.3232 & 1.0000 & & & & & & \\
\hline CEO & -0.2119 & -0.1565 & -0.1804 & 0.0339 & -0.0223 & 1.0000 & & & & & \\
\hline FORE & 0.1993 & 0.1603 & 0.3597 & 0.1217 & 0.3845 & 0.1210 & 1.000 & & & & \\
\hline AGE & 0.1541 & 0.0983 & 0.0242 & 0.1747 & 0.1078 & -0.3986 & 0.1603 & 1.0000 & & & \\
\hline FEBOD & 0.3430 & 0.2392 & 0.1353 & 0.1348 & 0.2065 & -0.2453 & 0.0853 & 0.1515 & 1.0000 & & \\
\hline BOS & -0.0195 & -0.0311 & -0.0628 & 0.1754 & -0.0134 & -0.1255 & 0.2195 & 0.0492 & 0.1126 & 1.0000 & \\
\hline FEBOS & 0.3296 & 0.2516 & 0.0793 & 0.0687 & 0.1092 & -0.2733 & -0.0639 & 0.1439 & 0.5040 & 0.2683 & 1.0000 \\
\hline
\end{tabular}

Source: Calculated from the Stata Analysis

There is a positive correlation between there dependent variables: ROA, ROE and Tobin's Q. Regarding ROA, the positive correlation can be seen from the number of female in BOD (FEBOD), the number of BOD (BOD), the number of foreigners in BOD (FORE), the average age of BOD (AGE) and the number of female in BOS (FEBOS). Independent director (ID) and CEO duality (CEO) have the negative correlation, which are -0.0068 and -0.3610 respectively. ROE and Tobin's Q have the similar correlation with ROA ratio, the only one difference is a positive correlation of independent directors.

\subsection{Finding and Analysis}

To define the suitable model for these variables, there are two tests would be made. Firstly, Breusch and Pagan Lagrangian Multiplier test are designed for choosing whether Pooled OLS or fixed effect and random effect method could give better results, respectively. The results for three dependent variables denoted that $\mathrm{P}$-value smaller than Alpha 5\%. Therefore, Random Effect Model is the chosen model for this analysis as well as provides more stable results than that of Pooled OLS.

\section{Table 3. Result of Breusch and Pagan Lagrangian Multiplier Test for random effect}

\begin{tabular}{|l|c|c|c|}
\hline Variables & ROA & ROE & TOBINSQ \\
\hline Chi-square & 187.98 & 96.30 & 523.18 \\
\hline Prob $>$ Chi-square & 0.0000 & 0.0000 & 0.0000 \\
\hline
\end{tabular}

Source: Calculated from the Stata Analysis

The next step is deciding whether fixed - effects model could be more appropriate than random - effects model or vice versa. Hausman test is used with the null hypothesis in favor of using random - effects and the alternatives support fixed - effects approach for estimations. The result indicated that the fixed-effect model was suitable for all three variables.

Table 4. Result equation for variables

\begin{tabular}{|l|c|c|c|c|c|c|}
\hline & ROA & P $>|\mathbf{z}|$ & ROE & P $>|\mathbf{z}|$ & TOBINQ & P $>|\mathbf{z}|$ \\
\hline BOD & -0.38958 & 0.083 & -0.78354 & 0.066 & -0.0194957 & 0.173 \\
\hline
\end{tabular}




\begin{tabular}{|l|c|c|c|c|c|c|}
\hline ID & 0.2901 & 0.409 & 1.29902 & 0.074 & 0.0293295 & 0.144 \\
\hline CEO & -0.87079 & 0.075 & -2.56204 & 0.021 & -0.1228213 & 0.139 \\
\hline AGE & 1.80396 & 0.037 & 2.83441 & 0.065 & 0.007268 & 0.905 \\
\hline FORE & 0.2614792 & 0.588 & 0.6274047 & 0.375 & 0.292067 & 0.475 \\
\hline FEBOD & -2.04616 & 0.142 & -2.13661 & 0.556 & -0.002624 & 0.868 \\
\hline BOS & -1.05788 & 0.031 & -2.18296 & 0.041 & -0.0132309 & 0.617 \\
\hline FEBOS & 1.3735 & 0.000 & 2.8092 & 0.000 & 0.0357807 & 0.014 \\
\hline
\end{tabular}

Source: Calculated from the Stata Analysis

Based on the outcome table, the number of people in BOD, the average age of director and CEO duality indicated significant result with firm performance, which measure by ROA and ROE. The dependent variable QTobin's does not show any significant relationship with those independent variables. Additionally, the number of people in BOS as well as the number of females in BOS also indicated a significant relationship with firm performance, both in ROA and ROE ratios. In general, the result of the regression analysis showed that the relationship between independent director, the number of women in BOD, the number of foreigners in BOD and firm performance is insignificant. The result obtained from this paper is not consistent with previous research.

The result equation will be as follow

\section{ROAi,t $=0.0749904-0.38958 \times$ BODi,t $-0.87079 \times$ CEOi,t $+0.037 \times$ AGEi,t $-1.05788 \times$ BOSi,t + $1.3735 \times$ FEBOSi,t \\ ROEi,t $=0.1758525-0.78354 \times$ BODi,t $+1.29902 \times$ IDi,t $-2.56204 \times$ CEOi,t $+2.83441 \times$ AGEi,t - $2.18296 \times$ BOSi,t $+2.8092 \times$ FEBOSi,t \\ TOBINSQi,t $=0.9189698+0.0357807 \times$ FEBOSi,t}

\section{Discussion}

There are several earlier studies conducted to confirm the strong relationship between the diversification on Board and firm performance. However, these studies can have difference approaches to finding the result as well as a different method for building the model. As a result, these researchers can lead to a variety of outcomes. In this study, the researcher using three dependent variables for measuring the operating efficiency of corporations, which are ROA, ROE and Tobin's Q. After analysing the model, there are many consistencies and inconsistencies between this study and previous ones.

Regarding the role of BOD, the diversification on Board only shows significant result in average age of member in BOD. Age averages give the strong evidence for a positive relationship with the firm performance. In this study, the reference frame is 45 because it is the average age of sample collected during the period of 5 years. It seems a reasonable result. In common sense, older director may have more time to improve their knowledge and understanding about the economic situation so they can use their experience in order to have better decision. This study will be more consistent if the data of education and experience is collected. But it is very difficult to collect as well as measure these two variables in a reasonable way. There are a few foreigners playing an important role in management position in Vietnamese companies, therefore, the sample size is not large enough for investigation.

Gender diversity in BOD is not consistent with many previous studies due to its insignificant outcome. In fact, almost all Board member in Vietnam are men and the proportion of women on Board is still quite low. Therefore, it will be difficult to analyze the effect of gender diversification in BOD. A similar explanation can be applied to the number of foreigners in BOD.

CEO duality also was considered as an important factor in other studies with a negative relationship with all dependent variables. This result supports for the theory that was mentioned in the literature review part. The principal - agent problem can be considered as a big issue in Vietnam due to the lack of fairness and transparency in the corporations. As a result, CEO duality can easily lead to conflict of interest in decision making process and managing business activities. In Vietnam, there is no compulsory rule or regulation of CEO duality, however, there is a significant trend of separation duties between CEO and Chairman in recent years. The result also can be easily observed by looking at the dataset. Almost all blue chip and good performance companies in the sample selection have the separation between CEO and Chairman. 
Regarding Supervisory Board, it shows a negative effect of both ROA and ROE ratio. This result indicated that the increase in the number of BOS member is not a good way for improve firm performance. Although many theories emphasize the important role in supporting and guiding of BOS in a company, the result is not consistent. One explanation can come from the independent perspective. Too many people working as independent members may lead to conflict in decision making among corporation. As a result, it will be negative influence on business activities. A highlight in the study is the significant result of gender diversification in BOS. This study implied the positive relationship between the gender diversification and firm performance.

In short, the different result presented in the study can comes from several reasons. In Tobin's Q ratio, the market capitalization was recorded based on by the stock price in the last trading day only; however, the stock price usually fluctuated throughout the year. As a result, the price collected did not show the right figure for market price of stock in the whole year and the variables' value may not accurately reflect the market value of companies. Moreover, Vietnamese market is not a perfect market so stock price sometimes does not properly reflect the market value of the company.

\section{Conclusion}

Board of Director can be seen as one of the most important entity in the corporation because they will decide for almost all business activities. In order to increase the effectiveness of Board of Director, there are several aspects should be considered carefully.

Firstly, CEO duality is one of the most debated topic recently. Many studies showed different results with variety explanations. This study supports for Agency theory about the necessary of separation between CEO and Chairman in a corporation. To improve the effectiveness of business activities, it is highly recommended that CEO duality should be avoid. The separation between CEO and Chairman would bring more benefit for firm by eliminate or at least reduce the conflict of interest in these two positions.

The diversification on Board becomes an interesting topic that was being investigated recently. Using panel data analysis, the study also confirms for the effective of diversification in Board in several components. Only age diversity on Board of Director and gender diversity on Supervisory Board are statistically significant and are important determinants of firm performance, which are measured by ROA, ROE.

To the end, our study can be extended by incorporating more controlled variables, larger sample and longer period data in the regression models to get better results. Other measures and methodology can also be employed.

\section{References}

[1] Adams, R., Daniel, F., 2009. - "Women in the boardroom and their impact on governance and performance", Journal of Financial Economics.

[2] Bart, F., Olga, D., Helena, C., 2016 - "The impact of cultural diversity in corporate boards on firm performance".

[3] Boyd, B. K., 1995, "CEO Duality and Firm Performance, A Contingency Mode", Strategic Management Journal, 16 (3): 301-312. 12.

[4] Boyd, B. K., Howard, M. and Carroll, W. O., 1997, "CEO Duality and Firm Performance: An International Comparison", In H. Thomas, D. O"Neal and M. Ghertman (eds), Strategy, Structure and Style, Chichester: John Wiley \& Sons, 23-39.

[5] Brickley, James A. and Coles, Jeffrey L. and Jarrell, Gregg A., "Corporate Leadership Structure: On the Separation of the Positions of CEO and Chairman of the Board". J Corp Finance 3:189-220.

[6] Carter, D. A., Simkins, B. J., \& Simpson, W. G. 2003. "Corporate governance, board diversity, and firm value". Financial Review, 38: 33- 53.

[7] Carter, D. A., D’Souza, F., Simkins, B. J., Simpson, W. G., 2010, “The Gender and Ethnic Diversity of US Boards and Board Committees and Firm Financial Performance", Corporate Governance: An International Review, Vol. 18, pp. 396-414.

[8] Chen, H., 2014 - "CEO duality and firm performance: an empirical study of EU listed firms"

[9] Chen, H., Hsu, W., Chang, C., 2016 - "Independent directors' human and social capital, firm internationalization and performance implications: An integrated agency-resource dependence view", International Business Review, Vol. 25, Issue 4, pp. 859-874.

[10] Cochran, P.L., Wood, R.A. and Jones, T.B., 1985 - The composition of boards of directors and incidence of golden parachutes. Academy of Management Journal, 28, 3, 664-671. 
[11] David, C., 2003 - "Corporate governance, board diversity and firm value", Journal of Business Ethics.

[12] Estélyi, K., Nisar, T., 2016 - "Diverse boards: why do firms get foreign nationals on their boards?" Journal of Corporate Finance 39, 174-192.

[13] Kristine, V., Chung-wen, C., 2017 - "CEO duality and bribery: the roles of gender and national culture", Management Decision, Vol. 55 Issue: 1, pp.218-231.

[14] Lorsch, J. W., 1989, "Pawns or Potentates: The Reality of America's Corporate Boards". Harvard Business School Press, Boston, MA.

[15] Mariassunta G., Mengxin, Z., 2015 - "Board ancestral diversity and firm performance volatility", European Corporate Governance Institute (ECGI) - Finance Working Paper No. 462/2016.

[16] Miletkov, M., Poulsen, A., Wintoki, M., 2017 - "Foreign independent directors and the quality of legal institutions", Journal of International Business Studies, Vol. 48, Issue 2, pp. 267 - 292.

[17] Murray, A., 1989 - “Top Management Group Hetero-geneity and Firm Performance”, Strategic Management Journal, 10, 125-142

[18] Maznevski, M. L., 1994 - "Understanding Our Differences: Performance in Decision-Making Groups with Diverse Members", Human Relations,47, 531-552

[19] Nermeen, F., 2013 - "Board diversity and firm performance: evidence from the UK SMEs", Applied Economics.

[20] Nermeen, F., 2013 - "How could board diversity influence corporate disclosure?", Corporate Board: Role, Duties \& Composition / Volume 9, Issue 3.

[21] Nielsen, S., \& Huse, M., 2010 - "The contribution of women on boards of directors: Going beyond the surface", Corporate Governance: An International Review, 18(2), 136-148.

[22] Nielsen, S., Huse, M., 2010 - "Women directors' contribution to board decision-making and strategic involvement: The role of equality perception", European Management Review, 7(1), 16- 29.

[23] Patton, A., \& Baker, J. C., 1987 - "Why Won’t Directors Rock the Boat", Harvard Business Review, 65(6), 10-18.

[24] Pi L., Timme, S.G., 1993 - "Corporate control and bank efficiency", Journal of Banking \& Finance, 17 (2) (1993), pp. 515-530

[25] Renée, B., Daniel, F., 2017 - "Women in the boardroom and their impact on governance and performance - gender".

[26] Ritchie, T., 2007 - "Independent Directors: Magic Bullet or Band-Aid?", Corporate Governance eJournal.

[27] Reguera-Alvarado, N., de Fuentes, P., \& Laffarga, J., 2015. Does Board Gender Diversity

[28] Robert, W., Khondkar E., Siyu L., 2016 - "The Effects of Board Independence and CEO Duality on Firm Performance: Evidence from the NASDAQ-100 Index with Controls for Endogeneity".

[29] Rosenstein, S., Wyatt, J., 1990. - "Outside directors, board independence, and shareholder wealth", Journal of Financial Economics, vol. 26, issue 2, 175 - 191.

[30] Ruigrok W., Peck S., Tacheva S., 2007 - "Nationality and Gender Diversity on Swiss Corporate Boards", Corporate Governance: An International Review, 15(4), 546-557.

[31] Shrader et al., 1997 - "Journal of Managerial Issues Women In Management And Firm Financial Performance: An Exploratory Study", Iowa State University.

[32] Simons, T., Pelled, L., \& Smith, K.,1999 - "Making Use of Difference: Diversity, Debate, and Decision Comprehensiveness in Top Management Teams", The Academy of Management Journal, 42(6), 662-673. Retrieved November 3, 2020, from

[33] Tricker, R.I. (1984). Corporate Governance: Practice, Procedures and Powers in British companies and their Boards of Directors (Aldershot, Hants., Gower). 